RAD Conference Proceedings, vol. 2, pp. 80-84, 2017

www.rad-proceedings.org

saborortty

\title{
CALCULATION OF THE EXPECTED DOSE FOR A RADIATION INCIDENT INVOLVING THE THEFT OF RADIOACTIVE SOURCES
}

\author{
Natasha Ivanova ${ }^{*}$, Severina Ivanova ${ }^{2}$ \\ ${ }^{1}$ Medical University “Prof. Dr. Paraskev Stoyanov”, Varna, Bulgaria \\ 2University Hospital "St. Marina”, Varna, Bulgaria
}

\begin{abstract}
On 10 September 2012, the Regional Health Inspectorate (RHI) in Varna received a signal for a radiation incident that occurred in Polimeri AD: three level switches, containing radionuclide cesium 137 had been stolen. The investigators found that the theft was carried out on 2 September 2012 by Roma residents of the residential area Gabena Mahala, Devnya. After the theft, the sources have been dismantled from their protective shielding and hidden in the neighborhood of the thieves. The sources were detected and removed from the living area after a joined action of the police department in Devnya, the Regional Health Inspectorate (RHI) Varna and the Civil Protection - Varna. Later, the radioactive sources were stored in the temporary repository for radioactive waste (RRW) of Polimeri AD. During the radiation incident and the elimination of the consequences the author of the article worked as an inspector physicist in the Department for Radiation Control at the Regional Health Inspectorate Varna and participated directly in all activities regarding the removal of the hidden resources and storing them in the repository for radioactive waste, as well as in all inspections and corrective actions.
\end{abstract}

Key words: Ionizing radiation, radiation accident, activity, dose received

DOI: $10.21175 /$ RadProc.2017.17

\section{PRELIMINARY INFORMATION}

Following facts were found in the process of investigation and inspections:

- The activity of the stolen radioactive sources corresponded to the initial activity written in the license issued by the Nuclear Regulatory Agency during the installation of the sources. Two of them showed activity of $96.2 \mathrm{GBq}$, and the third one $-32 \mathrm{MBq}$ [1].

- The handover protocols for delivery of the level switches contain the year of manufacturing, namely 1978. This means that an entire half-life period has passed, so the activity had a value, which was half of that (30.17 years half-life of cesium-137) measured at the initial installation [2].

- The conversation with the residents of Gabena Mahala revealed the places where the hidden radioactive sources were kept and the people being in direct and indirect contact with them, as well as the duration of this contact.

- An assessment for the expected doses from the incident was made, based on the data obtained from the examination of the residents and the information given by the Police Department and the Civil Protection about the contact of the residents with the radioactive sources [3].

\footnotetext{
*natasha i@abv.bg
}

- The repository for the radioactive waste of Polimeri $\mathrm{AD}$ was inspected several times. Adequate measures have been taken in order to comply with the actual legislation and achieving normal background dose rates for the zone outside the fence of the repository.

- In order to stop further misuse of the radioactive sources in Polimeri AD, the license for the use of the radioactive substances issued by the Nuclear Regulatory Agency was revoked. All remaining devices containing sources of ionizing radiation after the theft were dismounted and stowed for temporary storage in Polimeri $\mathrm{AD}$ and later transmitted for permanent storage in the Repository for Radioactive Waste in Novi Han $[3,4]$.

\section{ASSESSMENT OF THE DOSES RECEIVED DURING THE RADIATION INCIDENT IN POLIMERI AD, DEVNYA, VARNA REGION}

The calculations are made at following conventions:

- The doses were evaluated only for people being in close contact or near the sources of ionizing radiation for a long time.

- The data for the calculations were taken from the testimony of people who have been in contact with the radioactive sources. 
- Calculations are made without considering the tissue weight factor and the reduction coefficient for the bricks.

- The source is considered as point source.

- Only radiation in the air is taken into account, i.e. the calculations are performed for the surface of the hand (for any point of the hand at a distance $0.5 \mathrm{~mm}$ from the source) and a point of the body (for any point of the body at a distance $50 \mathrm{~cm}$ from the hand). Penetration of radiation in the hand and the body is not taken into account.

- For air an exposition of $\mathrm{X}=1 \mathrm{R}$ is considered, corresponding to a dose of $\mathrm{D}=8.7 \times 10^{-3} \mathrm{~Gy}$ [2]

- The dose $\mathrm{D}$ is calculated according to the expression [4]:

$$
D=\frac{\Gamma \times \mathrm{A} \times t}{r^{2}}
$$

where: D - absorbed dose;
$\Gamma$ - ionization constant or gamma constant, characterizing photon radionuclides;

A - activity of the radionuclide;

$\mathrm{t}$ - irradiation time;

$\mathrm{r}$ - distance from the source to the irradiated object.

- The gamma constant for Cs-137 is taken $\Gamma=3.242$ R.cm ${ }^{2}$.(h.mCi) ${ }^{-1}$ [2]. Its recalculated value (for SI) is: $21.34 \times 10^{-18}$ Gy.m ${ }^{2}$. (s.Bq) ${ }^{-1}$.

- The value of $44 \mathrm{GBq}$ is taken for the activity of one source. This is the activity at the moment of the incident for the more powerful source (96 GBq).

2.1. Residents of the residential area Gabena Mahala who were in direct contact with radioactive sources:

These are the individuals participating in the theft and dismantling of the lead shielding and the transportation to the places of hiding (on 9 September 2012). Later, two of the sources were buried in the ground near the house. (Table 1.)

Table 1. Calculated doses for the persons who were in contact with the radioactive sources for the longest period

\begin{tabular}{|c|c|c|c|c|c|c|c|}
\hline \multirow[b]{2}{*}{ 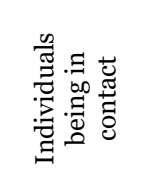 } & \multirow[b]{2}{*}{ 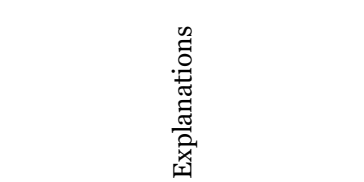 } & \multicolumn{3}{|c|}{ Initial data } & \multirow[b]{2}{*}{ 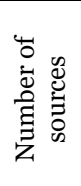 } & \multirow[b]{2}{*}{ 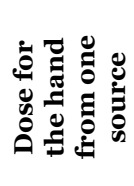 } & \multirow[b]{2}{*}{ 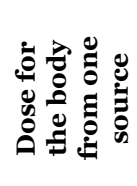 } \\
\hline & & 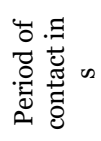 & 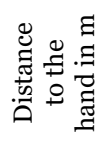 & 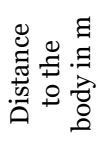 & & & \\
\hline $\begin{array}{l}\text { Male, } 39 \\
\text { years old }\end{array}$ & $\begin{array}{l}\text { Being in contact with the } \\
\text { radioactive sources for the } \\
\text { longest period; he was holding } \\
\text { them in his hand, carrying, } \\
\text { hiding and burying the } \\
\text { sources }\end{array}$ & 900 & 0.0005 & 0.5 & 2 & 3380 Gy & $\begin{array}{c}3 \cdot 4 \\
\mathbf{m G y}\end{array}$ \\
\hline $\begin{array}{c}\text { Child, } 9 \\
\text { years old, } \\
\text { girl }\end{array}$ & $\begin{array}{l}\text { Staying near the man during } \\
\text { the burial of the sources in the } \\
\text { ground. Did not touch the } \\
\text { sources. }\end{array}$ & 600 & - & 0.5 & 2 & - & $\begin{array}{c}2.3 \\
\text { mGy }\end{array}$ \\
\hline $\begin{array}{l}\text { Male, } 26 \\
\text { years old }\end{array}$ & $\begin{array}{l}\text { He dismantled the level } \\
\text { switches and was holding the } \\
\text { sources in his hand. The } \\
\text { dismantling lasted about ten } \\
\text { minutes. }\end{array}$ & 600 & 0.0005 & 0.5 & 1 & 2253 Gy & $\begin{array}{c}2.3 \\
\text { mGy }\end{array}$ \\
\hline $\begin{array}{l}\text { Male, } 16 \\
\text { years old }\end{array}$ & $\begin{array}{l}\text { He dismantled the level } \\
\text { switches and was holding the } \\
\text { sources in his hand. The } \\
\text { dismantling lasted about ten } \\
\text { minutes. }\end{array}$ & 600 & 0.0005 & 0.5 & 2 & 2253 Gy & $\begin{array}{l}2.3 \\
\mathbf{m G y}\end{array}$ \\
\hline $\begin{array}{l}\text { Male, } 33 \\
\text { years old }\end{array}$ & $\begin{array}{l}\text { He carried two of the sources } \\
\text { in a plastic bag. }\end{array}$ & 600 & 0.05 & 0.2 & 2 & 0.2 Gy & $14.1 \mathrm{mGy}$ \\
\hline
\end{tabular}

2.2. Residents of the residential area Gabena Mahala who stayed in the houses where radioactive sources were stored

House No.1 - Two sources were stored in a briefcase during 7 days (according to the testimony of the residents). The briefcase was placed in a room separating the two adjacent parts of the house. This room has one ruined wall. Two families live in the house, each having two children. All children slept in one room. The adult persons of both families slept in the two rooms at both sides of the room with the briefcase. The calculations are performed for the expected absorbed dose at a point of the body surface, supposed that the person stayed in the center of the room. The walls are brick walls $25-30 \mathrm{~cm}$ thick. The ceiling is a concrete slab of thickness of 20-25 cm. The calculations have not taken into account the absorption of the building materials. The calculations were made for three different periods of stay in the house: 24 hours, 16 hours and 8 hours (Table 2) [3].

House No.2 - Here one of the sources was stored during 7 days. The source was placed between the iron rods near the outdoor toilette, situated at about 10 meters from the house. A family with a newborn child of 5 months lives in the house. The calculations are made for the absorbed dose in a point of the body surface, where it is considered that the individual stayed near the outside wall of the outdoor toilette. The walls are brick walls $25-30 \mathrm{~cm}$ thick. The ceiling is a concrete slab of 
thickness $20-25 \mathrm{~cm}$. The calculations have not taken into account the absorption of the building materials. The calculations were made for three different periods of stay in the house: 24 hours, 16 hours and 8 hours (Table 3) [3].

Table 2. Calculated doses for the residents of House No. 1

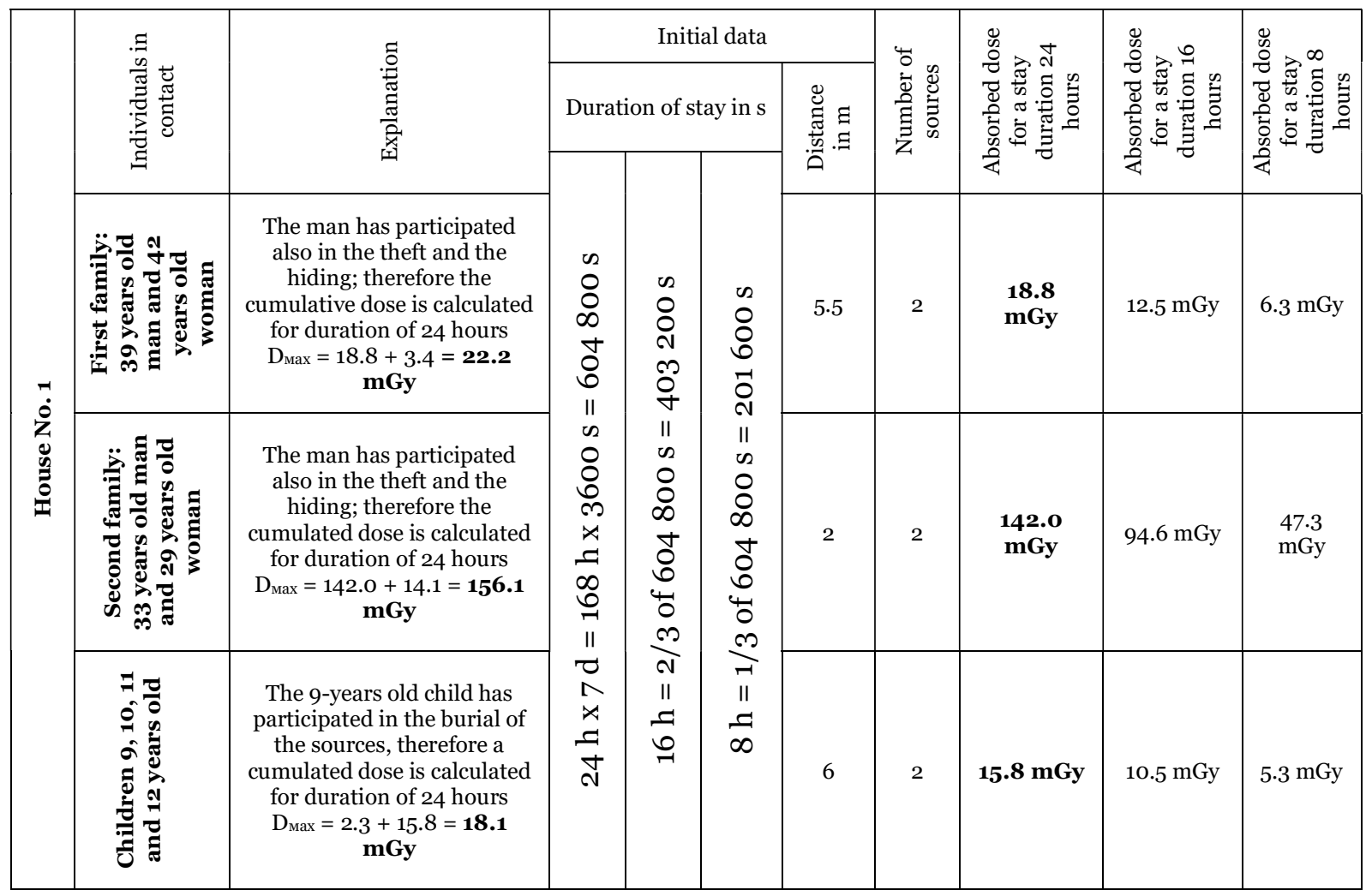

Table 3. Calculated doses of the residents of House No.2

\begin{tabular}{|c|c|c|c|c|c|c|c|c|c|c|}
\hline \multirow{4}{*}{ 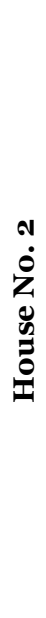 } & \multirow{3}{*}{ 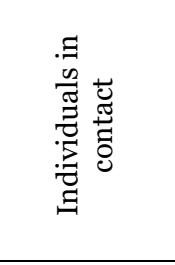 } & \multirow{3}{*}{ 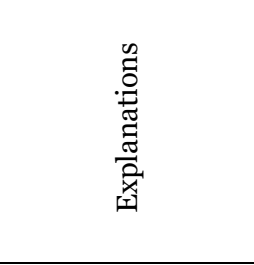 } & \multicolumn{4}{|c|}{ Initial data } & \multirow{3}{*}{ 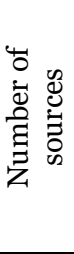 } & \multirow{3}{*}{ 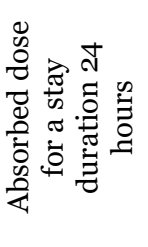 } & \multirow{3}{*}{ 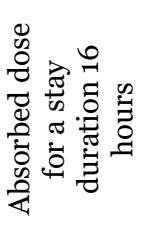 } & \multirow{3}{*}{ 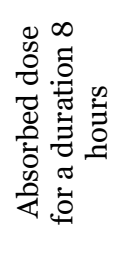 } \\
\hline & & & \multicolumn{3}{|c|}{ Stay duration in $\mathrm{s}$} & \multirow{2}{*}{ 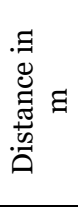 } & & & & \\
\hline & & & \multirow[b]{2}{*}{ 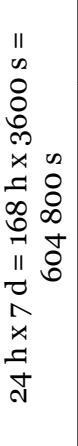 } & \multirow[b]{2}{*}{ 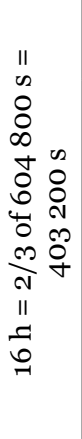 } & \multirow{2}{*}{ 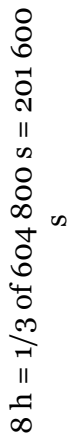 } & & & & & \\
\hline & 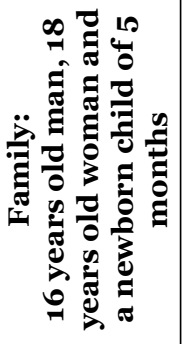 & $\begin{array}{l}\text { The man } \\
\text { participated in the } \\
\text { theft and the } \\
\text { storage; therefore } \\
\text { the cumulated } \\
\text { dose is calculated } \\
\text { for duration of } 24 \\
\text { hours } \\
\text { D }_{\text {мах }}=2.3+5.7= \\
\text { 8.0 } \mathbf{~ m G y}\end{array}$ & & & & 10 & 1 & $\begin{array}{c}\mathbf{5 \cdot 7} \\
\mathbf{m G y}\end{array}$ & $3.8 \mathrm{mGy}$ & $2.0 \mathrm{mGy}$ \\
\hline
\end{tabular}

2.3. Members of the team of professionals involved in the liquidation of the radiation incident

\section{- A team of civil protection}

These people entered the radioactive zone several times. During the night of 9 September 2012 they established two zones: $100 \mu \mathrm{Sv} / \mathrm{h}$ zone and $1 \mu \mathrm{Sv} / \mathrm{h}$ zone. They stayed within the border of each zone less than 10-
15 minutes: The first attempt to take one of the sources was made on 10 September 2012; the duration of stay in the zone was about 5 minutes on 10 September 2012 during the removal of all three sources from the radioactive area.

There was no direct proximity to the sources, but only a stay in the $1 \mu \mathrm{Sv} / \mathrm{h}$ zone. The duration of work in the zone lasted for less than 10 minutes. The estimation of the dose is done by supposing that the irradiation 
occurred from the three sources simultaneously for a period of $1 / 2$ hour for each of the two zones. The parameters were taken higher compared to the real situation (Table 4).

Table 4. Calculated doses for the officers

\begin{tabular}{|c|c|c|c|c|}
\hline & Duration in $\mathrm{s}$ & Distance in $\mathrm{m}$ & $\begin{array}{c}\text { Number of } \\
\text { sources }\end{array}$ & $\begin{array}{c}\text { Received dose from one } \\
\text { source }\end{array}$ \\
\hline $100 \mu \mathrm{Sv} / \mathrm{h}$ zone & $\mathbf{1 8 0 0}$ & $\mathbf{1}$ & $\mathbf{3}$ & $\mathbf{0 . 1 6 9} \mathbf{m G y}$ \\
\hline $1 \mu \mathrm{Sv} / \mathrm{h}$ zone & $\mathbf{1 8 0 0}$ & $\mathbf{1 0}$ & $\mathbf{3}$ & $\mathbf{0 . 0 0 2 m G y}$ \\
\hline
\end{tabular}

The maximal absorbed dose for one individual from one source is given by the following expression [3]:

$\mathrm{D}_{\text {мах }}=0.169+0.002=0.171 \mathrm{mGy}$

\section{- Team of Polimeri AD and team of the Police Department}

Both teams have entered the radioactive zone only once in the night of 9 September 2012, trying to localize the radioactive sources. They found only increased radiation and turned back.

During the night guard of the night of 9 to 10 September 2012, the police officers remained at safe distance outside the radioactive zone. Due to the fact that they were in indirect contact at a wide distance and for a short time, dose exposures were not calculated for them [3].

Table 5. Aggregated data from the calculations

\begin{tabular}{|c|c|c|c|c|c|}
\hline Individuals & $\begin{array}{l}\text { Dose received } \\
\text { on the hand } \\
\text { from one } \\
\text { source }\end{array}$ & $\begin{array}{c}\text { Dose received from } \\
\text { the dismantling } \\
\text { and carrying of the } \\
\text { source }\end{array}$ & $\begin{array}{c}\text { Dose received from } \\
\text { the hiding for } 24 \\
\text { hours storage }\end{array}$ & $\begin{array}{l}\text { Dose received } \\
\text { from one } \\
\text { source }\end{array}$ & $\begin{array}{l}\text { Number } \\
\text { of } \\
\text { sources }\end{array}$ \\
\hline Male, 39 years old & 3380 Gy & $3.4 \mathrm{mGy}$ & $18.8 \mathrm{mGy}$ & 22.2 mGy & 2 \\
\hline Female, 42 years old & - & - & $18.8 \mathrm{mGy}$ & $18.8 \mathrm{mGy}$ & 2 \\
\hline Male, 33 years old & $0.2 \mathrm{~Gy}$ & $14.1 \mathrm{mGy}$ & 142.0 mGy & $156.1 \mathrm{mGy}$ & 2 \\
\hline Female, 29 years old & - & - & 142.0 mGy & 142.0 mGy & 2 \\
\hline Child, 9 years old & - & $2.3 \mathrm{mGy}$ & $15.8 \mathrm{mGy}$ & $18.1 \mathrm{mGy}$ & 2 \\
\hline $\begin{array}{l}\text { Children, } 10,11 \text { and } 12 \\
\text { years old }\end{array}$ & - & - & $15.8 \mathrm{mGy}$ & $15.8 \mathrm{mGy}$ & 2 \\
\hline Male, 16 years old & 2253 Gy & $2.3 \mathrm{mGy}$ & $5.7 \mathrm{mGy}$ & 8.0 mGy & 1 \\
\hline Female, 18 years old & - & - & $5.7 \mathrm{mGy}$ & $5.7 \mathrm{mGy}$ & 1 \\
\hline $\begin{array}{l}\text { Newborn child of } 5 \\
\text { months }\end{array}$ & - & - & $5.7 \mathrm{mGy}$ & $5 \cdot 7 \mathbf{m G y}$ & 1 \\
\hline Male, 26 years old & 2253 Gy & $2.3 \mathrm{mGy}$ & $2.3 \mathrm{mGy}$ & $2.3 \mathrm{mGy}$ & 2 \\
\hline Officers & - & - & - & $0.171 \mathrm{mGy}$ & 3 \\
\hline
\end{tabular}

\section{CONCLUSIONS}

- Table 5 shows the doses calculated for any point on the hand and the maximal doses on a point of the body surface that could be received from the participating individuals of the radiation incident. Here are taken into account only the doses received during the hiding of the sources after the storage in the houses during 24 hours.

- Due to the close distance in the case of the contact with the sources, the calculated doses for hand are very high. The low dose is calculated for the face, which is not touched by hand being in contact with the sources.

- The maximum dose is received by the family members: a man, 33 years old (156.1 mGy) and a woman 29 years old (142.0 mGy). They have spent the longest time in the very proximity of the radiation sources. The dose received by the man is higher, because he participated directly in the theft, dismantling and hiding of the sources.

- The lowest doses are received by the officers (0.171 mGy), because they complied to radiation protection measures.

- Because of the very short time of contact (less than 15 minutes), the dose received during the dismantling and the transport of the sources is much lower than the dose received during the hiding of the sources, shown in Table 5 as 24 hours.

- One month of medical monitoring was carried out for the individuals who have had the longest contact. No abnormalities in their health were found. According to the information from the medical team, performing the monitoring, no clinical deviations from the normal health condition of the examined group were found. This fact leads to the conclusion that the period for contact with the source was much less than claimed by the affected persons. Thus, the received doses are lower.

- During the process of investigation in the Roma residential area, it was established that the inhabitants have some knowledge about the harmful effects of radiation, but they were not aware of the mechanism and the extent of the effect. The Roma participants were careful not to break the metal rod-shaped capsules containing the cesium sources. All three sources were found having intact metal capsules: two of the capsules were not damaged at all and the third one was slightly damaged. This has protected the individuals from receiving high dose exposures.

- In order to avoid this kind of radiation incidents, it is necessary to strengthen the radiation culture of the Roma population, focused on the security and protective measures concerning the storage and handling of radioactive sources. Increased caution should be exercised towards the control and protection from thefts 
of radioactive substances and strict compliance with the legal acts regulating the rules on radiation safety.

\section{REFERENCES}

1. В. Тодоров, Медицинска физика, София, България: Bristol-Myers Squibb Company, 2001, стр. 336. (V. Todorov, Medical physics, Sofia, Bulgaria: BristolMyers Squibb Company, 2002, p. 336.)

2. Г. Василев, Основни принципи на радиационната защита, София, България: Тита Консулт, 2008, стр. 73 и 125. (G.Vassilev, Basic principles of radiation protection, Sofia, Bulgaria: Theta Consult, 2008, pp. 73, 125.)
3. N. Ivanova, S. Ivanova, "Radiation incident in "Polimeri" Devnya, actions and safety measures: a case study," Ecology \& Safety, vol. 10, pp. 515-523, 2016.

Retrieved from:

https://www.scientificpublications.net/get/1000017/1482509635891347.pdf Retrieved on: Feb. 12, 2017

4. Агенция за ядрено регулиране. (о5.10.2012.). ПМС № 229 Наредба за Основните норми на радиационна защита. (Bulgarian Nuclear Regulatory Agency. (Oct. 5, 2012). PMS no. 229 Decree on Basic Norms for Radiation Protection.)

5. Retrieved from:

http://www.bnra.bg/bg/documents/legislation/regulatio ns/reg-onrz-2012.pdf

Retrieved on: Feb. 12, 2017 